\title{
Etik i arbejdslivet
}

$E$ thos, det græske ord for 'soedvane', og etik beskæftiger sig som regel med at udforske det gode i den menneskelige praksis, handling eller adfoerd. Eftersom at arbejde er at virke, at skabe, og dermed beskæftige sig med praksis og handling, må etik og etiske spørgsmål allerede i udgangspunktet være vævet ind i arbejdslivets mangfoldige udtryks- og udfoldelsesformer. Som det vil fremgå, er afsættet for denne indledning dermed, at etik altid i udgangspunktet er vævet ind i arbejdslivets praksisser. Det behøver dog slet ikke at være ensbetydende med, at vi indtager et hverken reflekteret eller refleksivt forhold til de etiske perspektiver. Som det vil fremgå i det følgende, er det faktisk oftere det modsatte, der er tilfældet: etiske spørgsmål forbliver tavse og ureflekterede. Det etiske er altid til stede, men er ofte foldet ind i arbejdslivets praksisser. Etiske perspektiver er vævet ind i den måde fagprofessioner handler på; den måde organisationer bliver kønnede; de opfordringsstrukturer som bæres ind med nye teknologier; den måde forandringsprocesser (u)intenderet ændrer på magtfordelingen på osv.

Dette temanummer bidrager med at åbne op for nogle få af de sorte bokse, som netop etiske spørgsmål udgør inden for arbejdslivsområdet. De forskellige bidrag tjener som potentielle eksemplariske cases på, hvordan vi andre kan anlægge etiske perspektiver på vores egne dilemmaer og paradokser inden for arbejdslivet. Det vil formentlig også allerede i indledningen stå klart, at den største udfordring ved at rejse et tema som etik i arbejdslivet er, at det bogstavelig talt er et Sisyfos arbejde, fordi etiske spørgsmål ingen absolutte eller essentielle svar kan give. At det synes at være et Sisyfos arbejde kan være årsagen til, at etik fylder så relativt lidt: Opgaven med at drøfte etiske perspektiver synes at være en uendelig opgave, som ingen absolutte svar giver og derfor meget let kan blive oplevet som en akademisk eller filosofisk øvelse. På samme tid, er etiske spørgsmål paradoksalt nok også allestedsnærværende, fordi de handler om vores hverdagspraksisser og fordi de, som nævnt ovenfor, er vævet ind i vores omgang med hinanden.

\section{Traditionen}

De vel nok mest kendte begreber og fænomener, som undertiden antager værktøjsmæssig karakter i udforskningen af det etiske, benævnes ofte dydsetik, pligtetik og nytteetik. I dydsetikken, som går helt tilbage til tiden omkring Aristoteles og Platon, rettes opmærksomheden ikke helt overraskende mod de dyder, der dyrker og udtrykker det gode liv. Pligtetikken retter opmærksomheden på regler for god handling. Handlingen bærer det etiske i sig og regler for den gode handling bliver afsættet for at anskueliggøre etiske praksisser. Sådanne etiske perspektiver har været nært knyttet til religiøse tilgange, hvori religionen foreskrev de gode handlinger. Men pligtetikken er i vid udstrækning også senere blevet knyttet til Kants kategoriske imperativ, hvori det hedder sig, at vi bør handle på måder, hvor grundlaget for vores 
beslutninger altid kan gælde som princip for mere almengyldige regler og principper. Nytteetikken siges ofte at stå i et paradoksalt eller dilemmafyldt forhold til disse etiske perspektiver, fordi nytteetikken har et langt mere formåls- og nytteorienteret sigte, som ofte vil kompromittere de dyds- og pligt-etiske fordringer. På den anden side synes nytteetiske perspektiver meget vanskelige at komme uden om i anvendelsesorienterede praksisser, når vi beskæftiger os med områder, hvor prioritering og begrænsede ressourcer spiller en rolle. Og dette synes ikke overraskende at gælde inden for de fleste områder, hvor arbejdsliv udfolder sig. Spændingerne mellem på den ene side dyds- og pligtetiske perspektiver som blandt andet udfolder sig i form af kritiske refleksioner i forhold til, hvordan vi udøver vores praksisser og $p a ̊$ den anden side, hvordan det påtrængende og tvangsmæssige krav om nødvendigheden af prioritering mellem forskellige valg sætter sig igennem i organiserede fællesskaber.

\section{Etik og modernitet}

I en tidlig modernitet og oplysningstankegang, hvor positivismen spillede en dominerende rolle, eksisterede der det, som undertiden kaldes en etisk objektivisme (Audi, 1999). Her syntes det et mål inden for det etiske at udforske og nærme sig identifikation af værdier, dyder, forpligtigelser, rettigheder mv. som var det fakta, der på tværs af kontekster kunne sige noget mere generelt om det etiske. Efterhånden har anerkendelsen af en samfundsskabt virkelighed vundet stadig større indpas, hvilket også har medført en større grad af etisk relativisme, hvor disse aspekter af etiske fordringer i stadig større grad anerkendes at være vævet ind i de institutionelle og kontekstuelle betingelser, hvor inden for det gode og mindre gode udspiller sig.

Udforskningen af etik knytter sig på tværs af disse perspektiver typisk til at udforske "det gode" og "det onde" (eller mindre gode), men adskiller sig i vid udstrækning med hensyn til hvorvidt der forfægtes en antagelse om, at der kan opnås generelle svar på etiske spørgsmål - som under den etiske objektivisme - eller endog kontekstuelt baserede "rigtige" svar på sådanne spørgsmål. I indledningen til et specialissue om etik, politik og organisering i tidsskriftet Organization, peger Martin Parker - som er professor inden for ledelsesog organisationsstudier og oftest udfordrer mainstream tænkning - på, at etik og politik typisk er adskilt for hverandre inden for $b u$ siness ethics. Her separeres forskellige typer af værdier til forskellige dele af hjernen skriver Parker: I højre side behandles ideer om, hvordan vi behandler andre mennesker i et analytisk og diskuterende samspil mellem intentioner og handlinger. I venstre side optræder de store værdimæssige spørgsmål som, hvordan samfund, markeder og institutioner spiller sammen (Parker, 2003, s. 187-8). De to dele adskilles ifølge Parker typisk (men ikke altid) inden for business ethics, hvor politik separeres, isoleres eller behandles som kontekstuel baggrundsstøj. I mange af disse studier knyttes altså oftest an til de tidligere nævnte etiske begreber som kategorisk imperativer dydsetik og pligtetik, der knyttes til umiddelbare lokale handlinger, som så diskuteres op imod nyttetik (Parker, 2003, s. 189). Parker forholder sig kritisk til, at det etiske i denne litteratur ofte ses afkoblet fra en større politisk kontekst, der danner rammen omkring, hvordan handlingerne udspiller sig i den lokale kontekst. Dette er for så vidt også en alvorlig kritik på det, vi ovenfor refererede til som etisk objektivisme. På flere punkter kan vi sige, at kritikken knytter sig an til en generel bevægelse i samfunds- og humanvidenskaberne. En sådan bevægelse kan identificeres på mangfoldige måder, men fremhæves her med afsæt i eksemplariske og klassiske tekster som fx Habermas' tiltrædelsesforelæsning Erkendelse og interesse (oprinde- 
ligt 1965, her (2005)), Berger og Luckmanns klassiske tekst The Social Construction of Reality fra 1966 (1992) eller Francois Lyotards senere skrift om The postmodern condition of knowledge, som oprindeligt er fra 1979 (1984). Parker forholder sig da også kritisk til, at der synes at være et fravær af en række af sådanne samfundsteoretiske og filosofiske perspektiver inden for business ethics (Parker, 2003, s. 189). Teksterne her har fokus på, hvordan værdier, interesser med videre er vævet ind i måden at erkende på. De diskuterer ikke i sig selv først og fremmest etik. Men de har hver især sine opgør med, hvordan erkendelse og viden skilles fra kontekst, fra praksis. Erkendelse og viden udskilles fra dér, hvor vaerdier og legitimitet skabes og reproduceres. Værdier og legitimitet, og dermed løsrivelsen af refleksioner om det gode og det mindre gode, isoleres fra vores erkendelsesprocesser, viden-skabelsesprocesser og vores arbejde med at gøre sådanne anvendelsesorienterede, fx når vi udvikler nye teknologier, når vi skaber nye systemer til at organisere arbejdet på osv. Det gælder både skabelsesprocesser, der angår viden, såvel i en akademisk som praktisk form.

De franske sociologer Boltanski og Thévenot udviklede i 90erne en samfundsmæssig analyse, hvori det moralske og etiske indskrives i retfærdiggørelsesregimer, hvor hvert regime har sin egen værdiordener, "order of worth". Det etiske og moralske antager nærmest grammatikalsk karakter inden for de forskellige regimer eller områder. En sådan grammatikalsk karakter sætter fokus på, at der ikke kan opnås en generel og dekontekstuel, objektiv forståelse af det etisk rigtige. En sådan er altid indskrevet kontekstuelt og henter sin betydning fra de institutionaliserede regler, som udgør det vi kunne kalde områdets grammatikalske regelsæt.

De nævnte forfatteres er således på trods af forskellene enige om at pege på, hvordan viden, interesse og værdi er vævet ind i fæ- nomener som teknologi og organisation. De forholder sig på forskellig vis kritisk til forestillingen om, at teknologi og organisation skabes og udvikles, som var de uhildede tekniske videnskaber, der griber ind $\mathrm{i}$ organisering og arbejdsliv på "selvtilfredse" måder uden at stille spørgsmål om, hvordan værdier og etik er vævet ind i disse, eller hvor det behandles overfladisk. Eller med andre ord giver disse bidrag anledning til nærmere at undersøge, hvordan etik er på færde i organiseringer og teknologier i arbejdslivet. Temanummeret her tager denne invitation op.

\section{Etiske perspektiver på moderne arbejdsliv}

Men hvordan udfoldes så forskellige tilgange til etiske perspektiver i relation til arbejdsliv sig så? Siden Webers identificering af en protestantisk arbejdsetik har det været erkendt, at mennesker har forskellige måder at forholde sig til deres arbejde på, og at dette involverer bestemte etikker. Webers forståelse af, hvordan protestantismen konfigurerer modernitet på en særlig måde, der tilbyder flittighed, opofrelse og særlige former for stræbsomhed som måder at blive til på som dydige og dermed anerkendelsesværdige mennesker, har haft stor betydning for den forskningsmæssige begribelse af moderne arbejdsliv. Denne forståelse har været grundlæggende for arbejdslivsforskningsfeltets konceptualicering af arbejde som noget, der har medkonstituerende betydninger langt uden for arbejdspladser og arbejdstid. Nyere arbejdslivsforskning har vist, at en protestantisk arbejdsetik om at arbejde hårdt og vedvarende ikke er nok til at indfri de etiske fordringer, der er indvævet i (post)moderne organisationers faglighed. Faglighed bliver dermed et etisk fænomen, der konstituerer de gode og anerkendelsesværdige ansatte og professionelle. Arbejdsetik rækker dermed 
langt udover selve arbejdet og ind i hverdagsliv og menneskers præferencer for hele tilværelsen. Højrups livsformsanalyse (Нøjrup, 1983a, 1983b) viste allerede for fire årtier siden, hvordan forskellige arbejdslivsorienteringer grundlæggende implicerer forskellige etiske funderinger af hverdagslivet. Man kan sige, at livsformanalysen i et etisk perspektiv udvider forståelsen af etik: Vi kan forstå etik som vores kontinuerlige valg om, hvad der er gode leve- og handlemåder, og dermed som en praktisk og konkret emergerende komponent i både arbejds- og hverdagsliv.

Temanummeret om etik i arbejdslivet undersøger derfor, hvordan forskellige former for arbejdsetik og arbejdsorienteringer ser ud i dag? Hvilke tanker om gode og ønskelige fagligheder og professionelle praksisser trives på arbejdsmarkedet? Og hvordan håndteres og afgøres de etiske dilemmaer, som professionelle hver dag anvender deres specifikke fagligheder i?

Med temanummeret om etik i arbejdslivet giver vi et indblik i nogle af de måder, hvorpå etik er involveret i menneskers arbejdsliv, og hvordan det kan undersøges og forstås. I forlængelse af etik som normer, der både tilbyder temanummeret fire artikler, der ser nærmere på forskellige etiske aspekter af arbejdslivet. Artiklerne spænder over en række teoretiske perspektiver på etik og viser flere slags arbejde med tilhørende etiske dilemmaer. Artiklernes analyser sætter fokus på, hvordan de konkrete arbejdsliv udfolder forskellige etiske perspektiver og levendegør etiske dilemmaer og paradokser. Flere af bidragene har teknologier og deres betydning for relationer mellem professionelle og borgere i fokus for de etiske dilemmaer i arbejdslivet. Etiske arbejdslivsdilemmaer, som knytter sig til teknologi og digitalisering er højaktuelt på rigtig mange arbejdspladser i disse år, og er derfor også et væsentligt tema, ikke bare i dette temanummer, men i hele arbejdslivsforskningen. Tilsammen viser de fire artikler en del af mangfoldigheden i de etikker, der findes, skabes og undertiden støder sammen i organisationer, fagligheder og professionelle relationer.

\section{Temanummerets bidrag}

I Etikkens kuperede terroen - etiske principper og etisk kompetence i socialt arbejde tilbyder Søren Engelsen, Regina Christiansen og Jakob Emiliussen en filosofisk undersøgelse og et vist opgør med top-down etiske perspektiver, hvor værditeoretiske og normative teorier i forlængelse af begreber som pligtetik, dydsetik og nyttetik bliver primære drivkræfter for en professionsetik. Undersøgelsen trækker på fænomenologiske pointer og trækker på eksempler fra et kvalitativt studie fra en kommunal ældrepleje. I artiklen mobiliseres som alternativ til de nævnte top-down etiske perspektiver, en professionsetisk fordring, der $\mathrm{i}$ et praksisorienteret perspektiv tillader et vis samspil af forskellige etiske principper som pejlemærker for den professionelle praksis. Det situations- og kontekstafhængige er grundlæggende nødvendigt for at reducere en ellers påtrængende kløft mellem princip og praksis, hvori etiske principper risikerer at blive katalysatorer for stadig større grøfter, dilemmaer, konfliktende interesser i en konkret og oplevet fagprofessionel praksis.

Annette Kamp og Stinne Aaløkke Ballegaard tager i artiklen Virtuel omsorg - Etik, ny professionalisme og forhandling af groenser fat på de etiske spørgsmål og dilemmaer, der aktualiseres af de såkaldte velfærdsteknologier, der introduceres i disse år i sundheds-og socialsektoren. Kamp og Ballegaard undersøger, hvordan indførelsen af skærmbesøg i hjemmeplejen er med til at introducere nye værdier omkring omsorg og understøtter nye former for professionalisme. Forfatternes tilgang til etik er empirisk og sætter fokus på etik som normative perspektiver, der udvikles og forhandles i en praksis. Artiklen 
viser hvordan etiske diskussioner udfoldes omkring nærhed og distance. Det danner grundlag for en diskussion af betydningen af at gøre medarbejderne til innovationsfortrop i en medarbejderdreven innovation, hvor grænserne for at bruge teknologien hele tiden udfordres.

I artiklen En teknologi på groensen - det etiske hensyn og det foelles bedste udforsker Mikkel Bøhm, Jan Bendtsen, Michael Jensen og Martin Brix Larsen brugen af kropskameraer inden for beredskabets operative indsatser. Artiklen tilbyder en praksisbaseret analyse af etiske dilemmaer, som blandt andet udspændes over de læringspotentialer, som anvendelsen af kropskameraer på den ene side bidrager med, men som samtidig også skaber potentielt sårbare positioner for aktørerne, hvis handlinger bliver gjort til genstand for analyser. Som det fremhæves i artiklens indledning, tager den afsæt "... i det paradoks, at det vi skal loere af, samtidig er det, der potentielt set gør os mest ondt".

Artiklen gennemfører en kontekstnær analyse og har et praksisbaseret sigte, som handler om at undersøge, hvordan arbejdet med videooptagelser fra operative indsatser kan tilrettelægges med henblik på at opløse det nævnte paradoks; altså at skabe læring uden at indskrive en uetisk sårbarhed. Artiklen trækker på konsekvensetikken for at udforske disse dilemmaer og bringer disse ind i en undersøgelse af læringsteamets rolle. Et team hvis rolle det er både at skabe mest mulig læring for at løse kerneopgaven, be- redskabsindsatser, men også at beskytte den enkelte medarbejder.

Bjørn Ribers præsenterer i Den humanitoere livsform - en ny epistemologi for den professionelle etos $i$ velfoerdsarbejde en udvidelse af livsformsanalysen, der introducerer en helt ny livsformskategori; den humanitære livsform. Ribers belyser, hvordan denne livsform er sammenvævet med professionsbegrebet, og udsprunget af velfærdsprofessionernes arbejde og placering i staten. Identificeringen af denne fjerde livsform sker på baggrund af et årtis forskning i velfærdsarbejde og professionsetik, og giver forfatteren grundlag for at diskutere den kompleksitet, som kendetegner velfærdprofessionernes arbejdsliv og eksistensmodus. Dette er særligt relevant i et etisk perspektiv, fordi Ribers påviser, at den humanitære livsform indebærer en professionsetisk bevidsthed som et essentielt bærende element for professionel integritet og som klangbunden for faglighed i professionelt velfærdsarbejde.

Temaredaktionen håber, at temanummeret om etik i arbejdslivet med disse forskellige etiske perspektiver og analyser kan bidrage meningsfuldt til de nødvendige diskussioner om etiske valg og implikationer af og i vores arbejdsliv, som er aktuelle for både forskningen og overalt $i$ arbejdslivet.

God loeselyst.

Peter Hagedorn-Rasmussen, Jo Krøjer \& Katia Dupret

\section{LITTERATUR}

Audi, R. (eds.) (1999). The Cambridge Dictionary of Philosophy. Cambridge

Berger \& Luckmann, B. (1992). Den samfundsskabte virkelighed: Lindhardt og Ringhof.

Boltanski, L. \& Thévenot, L. (2006). On justification: Economies of worth, 27: Princeton University Press.

Boltanski , L. \& Chiapello, E. (2005). The new spirit of capitalism: Verso. 
Habermas, J. (2005). Erkendelse og interesse. Teknik og videnskab som 'ideologi', 119-136: Det lille forlag.

Højrup, T. (1983a). Det glemte folk, livsformer og centraldirigering. Institut for Europæisk Folkelivsforskning, Statens Byggeforskningsinstitut.

Højrup, T. (1983b). The concept of life-mode, a form-specifying mode of analysis applied to contemporary Western Europe Ethnologia Scandinavica, 13, 15-50:
Jensen, U. J. (1984). Moralsk ansvar og menneskesyn: om holdninger i social-og sundhedssektoren. København: Munksgaard.

Lyotard, J. F. (1984). The postmodern condition: A report on knowledge, 10. University of Minnesota Press.

Parker, M. (2003). Introduction: Ethics, politics and organizing. Organization, 10(2), 187-203. 